\title{
BIBLIOGRAFIJA PROF. DR. JURIJA KUNAVERJA
}

\section{Znanstveni članki}

Visokogorski kras vzhodnih Julijskih in Kamniških Alp. Geografski vestnik 33 (1961), str. 95-135.

H geomorfološkemu razvoju Bovške kotline v pleistocenu. Geografski vestnik 47 (1975), str. 11-41.

Intenzivnost zakrasevanja in njegovi učinki v zahodnih Julijskih Alpah - Kaninsko pogorje. Geografski vestnik 50 (1978), str. 33-50.

Razvoj in sledovi zadnje stadialne poledenitve v Zgornjem Posočju. Geografski vestnik 52 (1980), str. 17-36.

Geomorfološki razvoj Kaninskega pogorja s posebnim ozirom na glaciokraške pojave. Geografski zbornik 22 (1982), str. 197-346.

The high mountains karst in the Slovene Alps. Geographica Iugoslavica 5 (1983), str. 15-23.

K problematiki geomorfološkega kartiranja in tipologije visokogorskega glaciokraškega reliefa. Acta carsologica 14/15 (1985/1986), str. 173-182.

O komparativnih metodah v geomorfologiji visokogorskega krasa. Geografski vestnik 59 (1987), str. 117-126.

H geomorfologiji dolomitnega prevala Vršič v Julijskih Alpah. Geografski vestnik 62 (1990), str. 79-98.

Spodmoli v stenah kraškega roba. Annales. Anali Koprskega primorja in bližnjih pokrajin 3 (1993), št. 3, str. 61-66. (Soavtor: Darko Ogrin)

The American geomorphology before W. M. Davis, with special regard to J. W. Powell and G. K. Gilbert = Ameriška geomorfologija pred W. M. Davisom s posebnim ozirom na J. W. Powella in G. K. Gilberta. Geografski zbornik 41 (2001), str. 167-181.

Contribution of Ivan Gams to the development of Slovene karst terminology. Acta carsologica 32 (2003), št. 2, str. 19-28.

Cave genesis in the Alps between the Miocene and today. Zeitschrift für Geomorphologie 50 (2006), št. 2, str. 153-176. (Soavtorji: Philippe Audra, Alfredo Bini, Franci Gabrovšek, Philipp Häuselmann, Fabien Hobléa, Pierre-Yves Jeannin, Michel Monbaron, France Šušteršič, Paola Tognini, Hubert Trimmel, Andres Wildberger)

Cave and karst evolution in the Alps and their relation to paleoclimate and paleotopography. Acta carsologica 36 (2007), št. 1, str. 53-67. (Soavtorji: Philippe Audra, Alfredo Bini, Franci Gabrovšek, Philipp Häuselmann, Fabien Hobléa, Pierre-Yves Jeannin, Michel Monbaron, France Šušteršič, Paola Tognini, Hubert Trimmel, Andres Wildberger)

Geomorfološke vsebine in njihova zastopanost v razlagi pokrajinskih značilnosti Triglavskega narodnega parka v primerjalni luči. Dela 2007, št. 28, str. 133-146. 
Novejša raziskovalna in pedagoška prizadevanja ter dosežki katedre za didaktiko geografije na ljubljanski univerzi. Dela 2009, št. 32, str. 73-84.

Ledeniška erozija v apnenčasti podlagi, da ali ne? Ob rob črnobeli geotektonski interpretaciji geomorfološke podobe Doline Triglavskih jezer. Dela 2012, št. 37, str. 147-161.

\section{Znanstveni prispevki v monografijah in zbornikih}

O razvoju slovenske terminologije za mikroreliefne kraške oblike. (Nekaj misli in predlogov ob primeru visokogorskega krasa). V: Slovenska kraška terminologija. Ljubljana, Katedra za fizično geografijo Oddelka za geografijo FF, 1973, str. 68-76. (Kraška terminologija jugoslovanskih narodov, 1)

The high mountainous karst of Julian Alps in the system of alpine karsts. V: Symposium on karst-morphogenesis. Papers. Szeged, Faculty of Science at Attila József University, 1973, str. 209-225.

Nekatere morfološke značilnosti reliefa v nizkem terciarnem svetu med Voglajno in Sotlo. V: Voglajnsko-sotelska Slovenija. Referati in material na plenarnem delu IX. zborovanja slovenskih geografov v Rogaški Slatini od 5. do 7. oktobra 1973. Ljubljana, Geografsko društvo Slovenije, 1974, str. 65-79.

Prispevek k prirodnogeografski tipologiji pokrajine v porečju Voglajne in zgornje Sotle. V: Voglajnsko-sotelska Slovenija. Referati in material na plenarnem delu IX. zborovanja slovenskih geografov v Rogaški Slatini od 5. do 7. oktobra 1973. Ljubljana, Geografsko društvo Slovenije, 1974, str. 47-64. (Soavtorji: Ivan Gams, Franc Lovrenčak, Darko Radinja)

Poglavitne značilnosti geomorfološkega razvoja Zgornjega Posočja. V: Zgornje Posočje. Zbornik 10. zborovanja slovenskih geografov, Tolmin - Bovec, 26.-28. 9. 1975. Ljubljana, Geografsko društvo Slovenije, 1978, str. 67-81. (Soavtor: Milan Šifrer)

Zgornje Posočje po potresu. V: Zgornje Posočje. Zbornik 10. zborovanja slovenskih geografov, Tolmin - Bovec, 26.-28. 9. 1975. Ljubljana, Geografsko društvo Slovenije, 1978, str. 9-13. (Soavtor: Milan Orožen Adamič)

Some experiences in measuring the surface karst denudation in high alpine environment. V: Actes du Symposium international sur l'érosion karstique, Aix-en-Provence - Marseille - Nîmes, 10-14 septembre 1979. Nîmes, Association Française de Karstologie, Museum d'Histoire Naturelle, 1979, str. 75-85. (Mémoire, 1)

Geografski pomen Triglavskega narodnega parka. V: Gorenjska. Referati in gradivo na 12. zborovanju slovenskih geografov v Kranju in na Bledu od 15. do 17. oktobra 1981. Ljubljana, Geografsko društvo Slovenije, 1981, str. 138-146.

O nekaterih problemih zbiranja in uporabe zemljepisnih imen v slovenskih Alpah. V: Zbornik radova Savjetovanja o pitanjima standardizacije geografskih naziva u jezicima naroda i narodnosti SFRJ. Sarajevo, Geografsko društvo Bosne i Hercegovine, 1984, str. 164-170.

Gozdne učne poti in njihova uporabnost pri terenskem pouku geografije. V: Gozdne učne poti v Sloveniji. Zbornik republiškega seminarja, Radovljica, 20. in 21. novembra 1986. Ljubljana, Biotehniška fakulteta, 1987, str. 37-50. 
Poznoglacialna poledenitev in njeni geomorfološki učinki v Zgornjem Posočju. V: Zbornik XII kongresa geografa Jugoslavije, održanog u Vojvodini od 29. septembra do 6. oktobra 1985. Novi Sad, Savez geografskih društava Jugoslavije, Geografsko društvo Vojvodine, 1987, str. 76-79.

Vidovska planota in geografske posledice njene obrobne lege. V: Notranjska. Zbornik 14. zborovanja slovenskih geografov, Postojna, 15.-17. oktobra 1987. Ljubljana, Zveza geografskih društev Slovenije, 1987, str. 35-47. (Soavtorica: Andreja Mestek)

Didaktika geografije včeraj, danes in jutri. V: Geografija in aktualna vprašanja prostorskega razvoja. 70 let geografije na ljubljanski univerzi. Ljubljana, Oddelek za geografijo Filozofske fakultete, 1989, str. 40-51. (Dela, 6)

Gorski svet Slovenije in njegova preobrazba. V: Slovenija 88. Okolje in razvoj. Ljubljana, Slovenska akademija znanosti in umetnosti, 1989, str. 68-81.

Znanje in izobraževanje. Varstvo okolja in pouk geografije. V: Slovenija 88. Okolje in razvoj. Ljubljana, Slovenska akademija znanosti in umetnosti, 1989, str. 191-194.

Some questions on geomorphological typification of high mountain karst. V: Problemy kompleksnogo izučenija karsta gornyh stran. Sbornik materialov Meždunarodnogo simpoziuma speleologov, SSSR, Tbilisi - Chaltubo - Suhumi, 5.-12. X. 1987. Tbilisi, Macniereba, 1989, str. 72-73.

Poznoglacialne morene v najvišjih delih posoških Julijskih Alp in poskus njihove datacije. V: Geomorfologija in geoekologija. Zbornik referatov 5. znanstvenega posvetovanja geomorfologov Jugoslavije, Krško, 18. do 23. junij 1990. Ljubljana, Znanstvenoraziskovalni center SAZU, 1990, str. 207-215.

Preval Vršič v Julijskih Alpah in denudacijsko-erozijski procesi v njegovem dolomitnem površju. V: Četvrti skup geomorfologa Jugoslavije, Pirot, 20.-23. juna 1989. Beograd, Geografski fakultet PMF, 1990, str. 125-134.

Corrosion terraces as geoecological response to postglacial development of glaciokarstic rock surface. V: Proceedings of the International conference on environmental changes in karst areas, I.C.E.C.K.A., Italy, September 15th-27th, 1991. Padova, Università di Padova, 1991, str. 325-331. (Quaderni del Dipartimento di geografia, 13)

Nekateri negativni pojavi v novejši preobrazbi pokrajinske podobe Zgornjega in Srednjega Posočja. V: Geografska problematika Severovzhodne Slovenije. Medinštitutski seminar Oddelka za geografijo Pedagoške fakultete v Mariboru in Oddelka za geografijo Filozofske fakultete v Ljubljani. Ob 30. letnici Oddelka za geografijo v Mariboru. Ljubljana, Oddelek za geografijo Filozofske fakultete Univerze v Ljubljani, 1991, str. 138-147. (Dela, 8)

Slovenia - a country of great natural variety. V: Slovenia. Geographic aspects of a new independent European nation. Ljubljana, The Association of the Geographical Societies of Slovenia, 1992, str. 21-30.

Exfoliation-generated rock shelters in limestone escarpments in western Dinaric Slovenia. V: Proceedings of the International symposium "Geomorphology and sea" and the Meeting of the Geomorphological Commission of the Carpatho-Balcan countries, Mali Lošinj, September 22-26, 1992. Zagreb, Geografski odjel Prirodoslovno-matematičkog fakulteta Sveučilišta u Zagrebu, 1993, str. 267-274. (Soavtor: Darko Ogrin) 
K problematiki zemljepisnih imen v dolinah Tolminke in Zadlašce. V: Dolini Tolminke in Zadlašce. Tolmin, Triglavski narodni park; Ljubljana, Republiški koordinacijski odbor Gibanja Znanost mladini pri Zvezi organizacij za tehnično kulturo Slovenije, 1993, str. 129-132. (Razprave in raziskave, 2)

Prispevek k poznavanju pokrajine in geomorfologije dolin Tolminke in Zadlašce. V: Dolini Tolminke in Zadlašce. Tolmin, Triglavski narodni park; Ljubljana, Republiški koordinacijski odbor Gibanja Znanost mladini pri Zvezi organizacij za tehnično kulturo Slovenije, 1993, str. 7-43. (Razprave in raziskave, 2)

Geografska podoba Slovenije ali bogastvo naravne pestrosti in prehodnosti. V: Informativni kulturološki zbornik. Ljubljana, Seminar slovenskega jezika, literature in kulture pri Oddelku za slovanske jezike in književnosti Filozofske fakultete, 1995, str. 9-18.

Geographical consequence of a peripheral and border location. The case of the Upper Soča Valley in the Slovenian Alps. V: Environment and quality of life in Central Europe. Problems of transition. Conference proceedings. Praha, Albertina icome, Faculty of Science, Charles University, 1995, [5 str.].

Plužna pri Bovcu. Primer transformacije obmejnega naselja, njegovega prebivalstva in zemljišča. V: Geografska problematika slovenskega alpskega sveta in slovenskih mest. Ljubljana, Oddelek za geografijo Filozofske fakultete,1995, str. 59-76. (Dela, 11)

Bovško. V: Regionalnogeografska monografija Slovenije. 1. del, Visokogorski alpski svet. Ljubljana, Znanstvenoraziskovalni center SAZU, Geografski inštitut, 1996, str. 58-88.

Environmental learning in geographical education on the example of Slovene Karst. $\mathrm{V}$ : Innovation in geographical education. Proceedings. Amsterdam, Centrum voor Educatieve Geografie Vrije Universiteit, 1996, str. 129-135.

On the location factor of the caves in Upper Soca Valley with special regard to the Kanin Mountains. V: Alpine caves. Alpine karst systems and their environmental context. Proceedings of the International congress, Asiago - Italy, June 11th-14th, 1992. Asiago, 1996, str. 275-282.

Tolminsko. V: Regionalnogeografska monografija Slovenije. 2. del, Zahodni predalpski svet. Ljubljana, Znanstvenoraziskovalni center SAZU, Geografski inštitut, 1996, str. 69-101.

Recent trends in geography teaching in Slovenia. A transitional and European perspective. V: Geographie und Erziehung. Festschrift für Hartwig Haubrich zum Abschied von der Pädagogischen Hochschule Freiburg. München, Lehrstuhl für Didaktik der Geographie der Universität, 1997, str. 159-168. (Münchner Studien zur Didaktik der Geographie, 10)

Development and forms of intercultural education in Slovenia with the special regard to geography teaching. V: Culture, geography and geographical education. Lisboa, Universidade Aberta, 1998, str. 214-218. (Proceedings, 1) (Soavtorica: Tatjana Resnik Planinc)

Šolska geografija v Sloveniji, njena evropskost in izkušnje kurikularne prenove $=$ Geography teaching in Slovenia, its European dimension and the experience of the curriculum reform. V: Evropská dimenze v geografickém vzdělávání. Sborník referátů z mezinárodní konference konané 25.-26. 3. 1998 v Ostravě. Ostrava, Ostravská univerzita, Př́rodovědecká fakulta, 1998, str. 134-151. 
Geomorfološki razvoj doline Krnice in njene zadnje poledenitve. V: Sonaravni razvoj v slovenskih Alpah in sosedstvu. Ljubljana, Oddelek za geografijo Filozofske fakultete, 1999, str. 63-75. (Dela, 13)

Šolska geografija v Sloveniji na prelomu stoletja. V: Razvojne možnosti Slovenije. Ljubljana, Oddelek za geografijo Filozofske fakultete, 1999, str. 77-90. (Dela, 14)

Didaktika geografije v Sloveniji med preteklostjo in prihodnostjo. V: Didaktični in metodični vidiki nadaljnjega razvoja izobraževanja. Zbornik prispevkov z mednarodnega znanstvenega posveta v Mariboru, 25. in 26. novembra 1999. Maribor, Pedagoška fakulteta, Oddelek za pedagogiko, psihologijo in didaktiko, 2000, str. 375-380.

Trenta. Geografske enote in krajevna imena. V: Trajnostni razvoj v slovenskem alpskem svetu. Zaključno poročilo. Ljubljana, Oddelek za geografijo, Filozofska fakulteta, 2000, str. 57-68.

Vojaška geografija v Sloveniji, med preteklostjo in prihodnostjo. V: Vojaška geografija v Sloveniji. Posvet, Ljubljana, maj 8.-9., 2000. Ljubljana, Generalštab Slovenske vojske in Oddelek za geografijo Filozofske fakultete, 2000, str. 25-32. (Dela, 15)

Obrobje in 'obrobje' v geografski podobi Slovenije na izbranih primerih. V: 37. seminar slovenskega jezika, literature in kulture, 25. 6.-14. 7. 2001. Zbornik predavanj. Ljubljana, Center za slovenščino kot drugi/tuji jezik pri Oddelku za slovanske jezike in književnosti Filozofske fakultete, 2001, str. 213-227.

Some remarks on the development and age of the great cave systems in the Kanin Mts., on the southern Slovenia side. V: Cave genesis in the Alpine belt. Proceedings of the 1st workshop for Alpine speleogenesis, Habkern (Switzerland), 10.-13. September, 2000. Fribourg, Institut de Géographie, Université de Fribourg, 2001, str. 141-151. (Rapports de recherche / Institut de Géographie, Université de Fribourg, 10) (Soavtor: Franci Gabrovšek)

Značilnosti reliefa v občini Cerkvenjak ter njegova pokrajinska funkcija. V: Podobe kraja. Zbornik občine Cerkvenjak. Cerkvenjak, Občina Cerkvenjak, Slovenskogoriški forum, 2001, str. 11-19.

Geography education for better international understanding, showing the example of Slovenia and its neighbourhood. V: IV. International conference on European dimension of teaching geography in the Middle, South Eastern and Eastern European countries in transition, Maribor, Slovenia, 2001. Ljubljana, Tiskarna Ozimek, 2002, str. 93-100.

Kraške vode Kaninskega pogorja in izviri pod njim s posebnim ozirom na Glijun. V: Soški razgovori I. Zbornik za domoznanstvo Zgodovinske sekcije KD Golobar. Bovec, Zgodovinska sekcija Kulturnega društva Golobar, 2002, str. 47-67. (Soavtor: Blaž Komac)

Reliefne in nekatere druge naravne značilnosti Bovške pokrajine. V: Bovški zbornik. Ob 800-letnici prve pisne omembe župnije Bovec, 1192-1992. Tolmin, Tolminski muzej, 2004, str. 99-128.

Novejša mednarodna prizadevanja za sodoben pouk geografije. Posebej o Mednarodni listini o geografski vzgoji in izobraževanju. V: Slovenska šolska geografija s pogledom v prihodnost. Ljubljana, DZS, 2005, str. 27-55. 
Nekatere geografske, zlasti reliefne poteze terskega dela Beneške Slovenije = Alcuni tratti geografici con particolari accenni alla Val Torre della Slavia Veneta. V: Terska dolina $=$ Alta Val Torre $=$ Val de Tor. Terska dolina $\mathrm{v}$ besedi, sliki in pesmi Viljema Černa. Celje, Društvo Mohorjeva družba, Celjska Mohorjeva družba; Gorica, Goriška Mohorjeva družba, 2006, str. 13-36.

Pohodniške in planinske poti po terskem delu Beneške Slovenije = Itinerari turistici della Valle del Torre della Slavia Veneta. V: Terska dolina $=$ Alta Val Torre $=$ Val de Tor. Terska dolina v besedi, sliki in pesmi Viljema Černa. Celje, Celjska Mohorjeva družba, Gorica, Goriška Mohorjeva družba, 2006, str. 47-54.

Corrosion terraces, a Megaausgleichsfläche or a specific landform of bare glaciokarst. V: Karst rock features. Karren sculpturing. Ljubljana, Založba ZRC, 2009, str. 161168. (Carsologica, 9)

The nature of limestone pavements in the central part of the southern Kanin Plateau (Kaninski podi), western Julian Alps. V: Karst rock features. Karren sculpturing. Ljubljana, Založba ZRC, 2009, str. 299-312. (Carsologica, 9)

Kocenovi učbeniki za geografijo, poskus didaktične analize. V: Blaž Kocen, 18211871. Življenje in delo očeta Kocenovih atlasov. Ljubljana, Slovenska matica, 2009, str. 39-51.

Bohinj kot pokrajina ledeniškega reliefa. V: Bohinjski zbornik II. Posvečeno 12-letnici Muzejskega društva Žiga Zois Bohinj ter 20-letnici sodelovanja Bohinjcev v osamosvojitveni vojni. Bohinj, Občina Bohinj, Turizem, 2012, str. 8-22.

\section{Strokovni in poljudni članki}

Brezno pri Medvedovi konti na Pokljuki. Poročilo o raziskovanju. Naše jame 2 (1960), št. $1 / 2$, str. $30-39$.

Terminologija visokogorskih kraških oblik. Geografski vestnik 34 (1962), str. 123-129. Visokoplaninski krš u Sloveniji. Geografski horizont 10 (1964), št. 1/2, str. 62-66.

Nekaj rezultatov speleoloških raziskav v Kaninskem pogorju 1963-1967. Naše jame 10 (1968), št. 1/2, str. 69-81.

Ob Soči navzdol do Tolmina. Pionir 23 (1968), št. 9, str. 8-9.

O nekaterih kvantitativnih metodah v sodobni geografiji. Geografski obzornik 17 (1970), št. 1, str. 8-13.

O geološkem razvoju nepalske Himalaje. Proteus 37 (1974/1975), št. 5, str. 232-239.

Geografija nepalskih pokrajin. Geografski obzornik 23 (1976), št. 1/2, str. 23-31.

Planinstvo in kras. Planinski vestnik 77 (1977), št. 4, str. 193-194.

Razprava o geografiji. Geografski vestnik 53 (1981), str. 85-92. (Soavtorji: Ivan Gams,

Peter Habič, Vladimir Klemenčič, Avguštin Lah, Darko Radinja, Igor Vrišer)

Apnenec + voda $=$ kras. Pionir 38 (okt. 1982), št. 2, str. 4-5.

Puščave niso samo peščene. Pionir 38 (dec. 1982), št. 4, str. 4-6.

Zemljin make-up ali o preperevanju. Pionir 38 (nov. 1982), št. 3, str. 28-30.

Znani in neznani Dinarski kras. Pionir 38 (sep. 1982), št. 1, str. 4-6. 
Domovina skritega ledu. Pionir 38 (maj 1983), št. 9, str. 3-6.

Ledeniki delujejo počasi, a temeljito. Pionir 38 (jan. 1983), št. 5, str. 3-6.

Luna - krater pri kraterju. Pionir 38 (jun. 1983), št. 10, str. 15-18.

Na robu kopnega. Pionir 38 (feb. 1983), št. 6, str. 3-6.

Ognjeniki - gorje in blagor. Pionir 38 (apr. 1983), št. 8, str. 3-5.

Zemlja je carstvo vode. Pionir 38 (mar. 1983), št. 7, str. 27-29.

O nastanku Alp in razvoju njenega površja. Geografski obzornik 31 (1984), št. 4, str. 4-16.

Permanentno izobraževanje učiteljev geografije na osnovnih šolah. Geografski obzornik 31 (1984), št. 2/3, str. 98-103.

Prenova šolskih programov in geografija Jugoslavije. Geografski obzornik 33 (1986), št. 4, str. 3-4.

Kras v slovenskih geografskih učbenikih. Geografski obzornik 34 (1987), št. 2, str. $16-23$.

Kraške mize pri nas in na tujem. Proteus 50 (1987/1988), št. 7, str. 263-268.

Drobne kraške oblike golega krasa. Proteus 51 (1988/1989), št. 3, str. 103-105.

Ugotavljanje erozije prsti v domači pokrajini. Geografski obzornik 36 (1989), št. 3/4, str. 15-19.

Inovacije pri pouku geografije. Geografski obzornik 37 (1990), št. 2, str. 10-15.

Ujme naravnih in človeških sil. Gorski svet Slovenije in njegova preobrazba. Planinski vestnik 90 (1990), št. 7/8, str. 302-306.

O 'političnosti' pouka geografije in vlogi politične geografije pri njem. Geografija v šoli 1 (1991), str. 89-93.

Ob bregovih Soče. Planinski vestnik 91 (1991), št. 6, str. 274-277.

'Mednarodnost' slovenske geografije. Geografski obzornik 39 (1992), št. 3, str. 3.

$\mathrm{O}$ položaju in nalogah klimatogeografskih vsebin pri pouku geografije. Geografija v šoli 2 (1992), str. 61-65.

Polarni pokrajinski tipi in tundra. Geografski obzornik 39 (1992), št. 2, str. 16-20.

Življenjske razmere in varstvo okolja v polarnih krajih. Geografski obzornik 39 (1992), št. 4, str. 10-14.

Mednarodni test geografskega znanja Intergeo II in uspeh slovenskih osmošolcev. Geografija v šoli 3 (1993), str. 90-100.

Pokrajinski opisi v književnosti in njihov didaktični pomen pri pouku geografije. Geografija v šoli 4 (1995), št. 1, str. 47-53.

Problemi pouka geografije v Sloveniji v luči kurikularne prenove. Geografija v šoli 5 (1996), št. 3, str. 3-9.

10 let Ilešičevih dnevov in stalno spopolnjevanje učiteljev geografije. Geografija v šoli 6 (1997), št. 2/3, str. 2-6.

O dveh geografskih ekskurzijah v Alpe in soseščino, o izbiri poti in strokovni učinkovitosti. Geografski obzornik 44 (1997), št. 4, str. 11-15.

O nastanku in pomenu renskega tektonskega jarka in sosedstva. Geografski obzornik 44 (1997), št. 3, str. 11-18.

Problem okoljskih vsebin pri pouku geografije doma in po svetu. Geografija v šoli 6 (1997), št. 1, str. 28-34. 
Slowenien. Unbekannte Vielfalt. Geographie heute 18 (1997), št. 153, str. 8-11.

Še o geografiji. Delo 39 (6. jan. 1997), št. 3, str. 4. (Soavtorja: Mirko Pak, Franc Lovrenčak)

Erozija prsti in boj proti njej na Velikih ravninah - Great Plains v ZDA. Priprava na tematski pouk s primerom. Geografija v šoli 7 (1998), št. 1, str. 29-36.

Kot prelomnica sv. Andreja ... . Velikonočni potres v Zgornjem Posočju - naravni pojav z mnogimi posledicami. Grif 1998, št. 21, str. 26-27.

Obetajo se še številna odkritja. Kaninsko pogorje - pestrost visokogorskega krasa. Delo 40 (15. jul. 1998), št. 161, str. 11.

Kako nas ocenjujejo nekateri študenti? Ali, kdor drugemu jamo koplje, je sam svoje sreče kovač! Geomix 6 (2000), št. 1, str. 24-25.

So Jadransko morje nekoč hladili ledeniki? Delo 43 (25. avg. 2001), št. 196, str. 30.

Koloradska planota in kanjonske pokrajine jugozahodnega Utaha. Geografski obzornik 49 (2002), št. 2, str. 3-8.

Naravni parki in naravne znamenitosti v zgornjem toku rek Kolorado, Green River in San Juan. Geografski obzornik 49 (2002), št. 3, str. 3-11.

Strokovni in osebnostni razvoj učitelja geografije v vseh življenjskih obdobjih. Geografija v šoli 11 (2002), št. 1, str. 3-9.

Moja prihodnost v Evropi - kako jo dojemajo srednješolci. Geografija v šoli 13 (2004), št. 1, str. 46-53. (Soavtorica: Maja Besednjak)

Prva leta kaninskega jamarstva, 1963-1967. Glas podzemlja. Glasilo društva za raziskovanje jam Ljubljana 2004, št. 1, str. 57-60.

Ponovno o spodmolih na Velem Badinu in njihovem nastanku. Geologija. Proteus 69 (2006/2007), št. 9/10, str. 417-428.

Smrdeče mlake namesto planinskih biserov. Dolina sedmerih jezer po 100 letih in predlog novega zakona o Triglavskem narodnem parku. Delo 50 (6. mar. 2008), št. 54, str. 21.

Znanstvena in strokovna raven prispevkov v reviji Geografija v šoli. Geografija v šoli 18 (2009), št. 2, str. 62-69.

Pokljuška soteska, izjemna naravna znamenitost - lahko dostopen cilj šolske ekskurzije. Geografija v šoli 19 (2010), št. 1, str. 22-32.

Svalbard. Arktični glaciološki in ekološki laboratorij Evrope. Geografski obzornik 57 (2010), št. 2, str. 4-13.

Svalbard. Naravna pestrost arktične pokrajine. Geografski obzornik 57 (2010), št. 3/4, str. 4-14.

Islandski vulkanizem v luči izbruha vulkana Eyjafjallajökull (2010). Geografija v šoli 20 (2011), št. 1, str. 28-38.

Vulkanski katastrofi na otoku Heimaey. Geografija v šoli 20 (2011), št. 2, str. 54-58.

Kocenov atlas na Bližnjem vzhodu. Spominski zapis ob 150-letnici prvega Kocenovega atlasa. Geografski vestnik 84 (2012), št. 2, str. 114-117.

Ledeniki. Večni ali minljivi? Gea 22 (2012), št. 11, str. 18-31.

Pod Makalujem s Tonetom Wraberjem in Janezom Gregorijem pred štiridesetimi leti. Proteus 75 (2012/2013), št. 1, str. 7-15. 


\section{Strokovni prispevki v monografijah in zbornikih}

Nekatere fizično-geografske poteze Izlaške pokrajine. (Poročilo fizično-geografske skupine). V: Mladinski raziskovalni tabori 1970, Cerknica, Piran, Izlake. Ljubljana, Republiški odbor gibanja 'Znanost mladini', 1971, str. 199-214.

Če geograf potuje. V: Makalu, Ljubljana, Mladinska knjiga, 1974, str. 53-72.

S kladivom in kompasom po dolini Baruna. V: Makalu. Ljubljana, Mladinska knjiga, 1974, str. 101-108.

Bovška kotlina. V: Vodnik ekskurzij po Zgornjem Posočju. Ljubljana, Geografsko društvo Slovenije, 1975, str. 20-24.

Kaninsko pogorje. V: Vodnik ekskurzij po Zgornjem Posočju. Ljubljana, Geografsko društvo Slovenije, 1975, str. 24-26.

Od Bovca do Kala-Koritnice. V: Vodnik ekskurzij po Zgornjem Posočju. Ljubljana, Geografsko društvo Slovenije, 1975, str. 27-28.

Od Kobarida do Žage. V: Vodnik ekskurzij po Zgornjem Posočju. Ljubljana, Geografsko društvo Slovenije, 1975, str. 17-20.

Od Soče do Zadnje Trente. V: Vodnik ekskurzij po Zgornjem Posočju. Ljubljana, Geografsko društvo Slovenije, 1975, str. 32-35.

Od Tolmina do Kobarida. V: Vodnik ekskurzij po Zgornjem Posočju. Ljubljana, Geografsko društvo Slovenije, 1975, str. 11-13.

Sinji vrh-Stari trg (Poljanska dolina in dolina zgornje Kolpe). V: Vodnik ekskurzije po Beli krajini in osrednji Dolenjski. Ljubljana, Geografsko društvo Slovenije, 1984, str. 44-60.

Relief. V: A guide to the Triglav National Park. Bled, Triglavski narodni park, 1987, str. 30-60.

Alpski mladinski raziskovalni tabori v Bovcu, 1985-1987. V: Pokrajina in ljudje na Bovškem. Ljubljana, Republiški koordinacijski odbor Gibanja Znanost mladini pri Zvezi organizacij za tehnično kulturo Slovenije, 1988, str. 5-8.

Zemljepisna imena $\mathrm{v}$ visokogorskem svetu in njihova uporaba na primeru Rombona in Goričice. V: Pokrajina in ljudje na Bovškem. Ljubljana, Republiški koordinacijski odbor Gibanja Znanost mladini pri Zvezi organizacij za tehnično kulturo Slovenije, 1988, str. 125-132.

Der Raum Flitsch in der Nachkriegszeit aus der Sicht seiner Grenz- und Randlage. V: Isonzo-Protokoll. Klagenfurt, Ljubljana, Wien, Hermagoras/Mohorjeva, 1994, str. 265-283.

Povojna usoda Bovškega v luči obmejnosti in perifernosti. V: Soški protokol. Celovec, Ljubljana, Dunaj, Mohorjeva založba, 1994, str. 227-242.

Tri rojstva Himalaje - Makalu '72'. V: Od Triglava do treh vrhov sveta. Radovljica, Didakta, 1994, str. 194-195.

Specifičnosti slovenskega geografskega prostora v primerjavi z evropskim sosedstvom.

V: Zbornik predavanj. XXXI. seminar slovenskega jezika, literature in kulture, 26. 6.-15. 7. 1995. Ljubljana, Filozofska fakulteta, Oddelek za slovanske jezike in književnosti, 1995, str. 213-217. 
Julijske Alpe. V: Slovenija. Pokrajine in ljudje. Ljubljana, Mladinska knjiga, 1998, str. 54-70.

Julijske Alpe. V: Slovenija. Pokrajine in ljudje. 2. izd. Ljubljana, Mladinska knjiga, 1999, str. 54-70.

Julijske Alpe. V: Slovenija. Pokrajine in ljudje. 3. izd. Ljubljana, Mladinska knjiga, 2001, str. 54-70.

Dolina Iške in značilnosti njene geomorfološke podobe in razvoja. V: Iška in Iški Vintgar. Ljubljana, samozal., 2001, str. 16-20.

Alpine karst of Kanin massif. Geographical position. V: Evolution of karst: from prekarst to cessation. Programme and guide booklet for the excursions, September, 17th-21st, 2002. Postojna, Karst Research Institute ZRC SAZU, 2002, str. 1. (Soavtor: Franci Gabrovšek)

Alpine karst of Kanin massif. Geomorphology and morphogenesis. V: Evolution of karst: from prekarst to cessation. Programme and guide booklet for the excursions, September, 17th-21st, 2002. Postojna, Karst Research Institute ZRC SAZU, 2002, str. 4-6.

Mt. Kanin. Alpine karst of Kanin massif. V: Zbornik. Mednarodni geološki tabor EUGEN 2003, Kobarid, Slovenija. Ljubljana, Zveza za tehnično kulturo Slovenije, Gibanje znanost mladini, 2003, str. 107-109. (Soavtorja: Franci Gabrovšek, Bojan Otoničar)

O geoloških in reliefnih značilnostih Alp. V: Slovenski alpski svet in Alpska konvencija. Ljubljana, Svet za varstvo okolja Republike Slovenije, 2003, str. 25-33. (Usklajeno in sonaravno, 10)

Poročilo o možnostih za čezmejno sodelovanje v naravoslovju med Občino Bovec in zamejskimi Slovenci ter njihovimi organizacijami v sosednjih italijanskih občinah. V: Občina Bovec in slovenski zamejci v Italiji. Priročnik za sodelovanje. Bovec, Občina Bovec, 2003, str. 81-87.

Relief. V: Narava Slovenije. Ljubljana, Mladinska knjiga, 2004, str. 45-71.

Relief slovenskih Alp. V: Narava Slovenije. Alpe. Ljubljana, Prirodoslovni muzej Slovenije, 2004, str. 23-29. (Razstavni katalog)

Visokogorski kras v slovenskih Alpah. V: Narava Slovenije. Alpe. Ljubljana, Prirodoslovni muzej Slovenije, 2004, str. 30-34. (Razstavni katalog)

Ekskurzija 1. Geomorfološke značilnosti vršnega dela Pohorja. V: Vodnik po programu, ekskurzijah, predavanjih in povzetkih posterjev. Ljubljana, Geomorfološko društvo Slovenije, 2005, str. 5-14. (Soavtorja: Ivan Gams, Karel Natek)

Moč sonca, vode, vetra ... . V: Kaj spreminja svet. Ljubljana, Prirodoslovni muzej Slovenije, Agencija RS za okolje, 2006, str. 55-80. (Soavtorja: Uroš Herlec, Miha Jeršek)

Bovec, Slovenia. V: Friuli 1976. Storie, voci, ricordi. Venezia, Provincia di Venezia, Assessorato alla Protezione Civile, 2007, str. 67-85. (Soavtor: Renato Vidrih)

Pomen, značilnosti in vrednote ekskurzij v okviru študijske skupine Geografija Slovenije Univerze za tretje življenjsko obdobje Ljubljana. V: Geografske ekskurzije po Sloveniji in izven nje, 2000-2004. Ljubljana, Univerza za tretje življenjsko obdobje, Prva študijska skupina Geografija Slovenije, 2007, str. 9-14. 
Predavatelji in učenci v poznejših letih življenja so vsi pol prazna in pol polna posoda implikacije tega dejstva za študij geografije. V: Posebnosti izobraževanja starejših. Ljubljana, Društvo za tretje življenjsko obdobje, 2012, str. 104-119. URL: http:// www.slovenska-univerza3.si/docs/eMonografija_Posebnosti_izobrazevanja_starejsih.pdf (Citirano 24. 9. 2013).

Spomini na izjemno leto 1963 in na Najdeno jamo. V: Jubilejna izdaja ob 50-letnici preboja Radeščkove pasaže. Ljubljana, Društvo za raziskovanje jam, 2013, str. 46-47. (Glas podzemlja)

\section{Diplomsko delo}

Visokogorski kras v vzhodnih Julijskih in Kamniških Alpah. Ljubljana, Prirodoslovno-matematična fakulteta Univerze v Ljubljani, 1958.

\section{Doktorska disertacija}

Geomorfološki razvoj Kaninskega pogorja s posebnim ozirom na razvoj glaciokraškega reliefa. Ljubljana, Filozofska fakulteta Univerze v Ljubljani, 1972.

\section{Samostojne publikacije}

Guide through the high-mountainous karst of the Julian Alps. 4th International Speleological Congress. Pre-congress excursion. Ljubljana, 1965, 40 str.

Field trip guide to the excursion B - The upland Dinaric karst - Trnovski gozd and glaciokarst of the western Julian Alps - Mt. Kanin, 4.-5. September 1975. Ljubljana, Filozofska fakulteta, Oddelek za geografijo, 1975, 29 str. (Soavtor: Peter Habič)

Naš alpski svet. Ljubljana, Mladinska knjiga, 1979, 36 str. (Zbirka Pelikan)

Ekskurzije naravoslovnih krožkov. 9, Bloška planota. Ljubljana, Prirodoslovno društvo Slovenije, 1984, 27 str. (Soavtor: Stane Peterlin)

Naš alpski svet. Ljubljana, Mladinska knjiga, 1984, 36 str. (Zbirka Pelikan)

Ob bregovih Soče. Ljubljana, Mladinska knjiga, 1991, 32 str. (Zbirka Pelikan)

Naš alpski svet. 2. popravljeni ponatis. Ljubljana, Mladinska knjiga, 1992, 32 str. (Zbirka Pelikan)

Vodnik po ekskurziji klasikov: Ljubljana-Rateče-Trbiž-Rabelj-Log pod MangrtomBovec-Log v Trenti-Vršič-Ljubljana, 5. 10. 2006. Ljubljana, Društvo klasikov, 2006, 12 str. (Soavtorji: Blaž Komac, Nataša Gliha Komac, Vlado Lipovec)

Učne poti po Ponikvi. Kraška vodna učna pot Stanka Buserja: pot treh znamenitih ponkovških mož. Ponikva, Turistično olepševalno društvo Ponikva, 2010, 28 str. (Soavtorji: Ana Vovk Korže, Tomislav Golob, Nina Rman)

Kaninsko pogorje in učna pot na Prestreljeniških podih. Naravoslovni, zgodovinski in turistični vodnik. Bovec, Turistično društvo, 2011, 168 str.

Kocenov srednješolski atlas kot didaktična prelomnica. Ljubljana, Založba ZRC, 2011, 120 str. (Geografija Slovenije, 22) (Soavtorji: Rožle Bratec Mrvar, Lukas Birsak, Jerneja Fridl, Drago Kladnik) 


\section{Učbeniki in drugo učno gradivo}

Geografija. Poskusni učbenik. Ljubljana, Mladinska knjiga, 1981, 113 str. (Srednje izobraževanje) (Soavtorji: Slavko Brinovec, Anton Gosar, Marijan M. Klemenčič, Vladimir Klemenčič, Franc Lovrenčak, Mirko Pak, Marija Košak, Darko Radinja, Igor Vrišer, Marjan Žagar)

1. ponatis, 1982

Geografia. Libro di testo sperimentale. Ljubljana, Mladinska knjiga, 1982, 113 str. (Istruzione media fondo comune di contenuti educativi e istruttivi base) (Soavtorji: Slavko Brinovec, Anton Gosar, Marijan M. Klemenčič, Vladimir Klemenčič, Franc Lovrenčak, Mirko Pak, Marija Košak, Darko Radinja, Igor Vrišer, Marjan Žagar)

Geografija 3. Geografske značilnosti in sodobni problemi Slovenije in Jugoslavije. 1. Spoznavanje in proučevanje domače regije. Ljubljana, Mladinska knjiga, 1981, 74 str. (Srednje usmerjeno izobraževanje) (Soavtorji: Božidar Kert, Marijan M. Klemenčič, Mirko Pak)

Geografija 3. Geografske značilnosti in sodobni problemi Slovenije in Jugoslavije. 2. Geografske značilnosti Slovenije. Ljubljana, Mladinska knjiga, 1982, 86 str. (Srednje usmerjeno izobraževanje) (Soavtor: Marijan M. Klemenčič)

Geografija 1. Ljubljana, Mladinska knjiga, 1986, 123 str. (Srednje izobraževanje) (Soavtorji: Slavko Brinovec, Anton Gosar, Marijan M. Klemenčič, Vladimir Klemenčič, Franc Lovrenčak, Mirko Pak, Dušan Plut, Marija Košak, Darko Radinja, Igor Vrišer)

Dopolnjena izd., 1987.

Dopolnjena izd., 3. natis, 1989.

Dopolnjena izd., 4. popravljeni natis, 1990.

Dopolnjena izd., 5. popravljeni natis, 1991.

Dopolnjena izd., 6. popravljeni natis, 1992.

Dopolnjena izd., 7. natis, 1993.

Dopolnjena izd., 8. natis, 1994.

Geografija. Domača pokrajina. Priročnik za geografsko spoznavanje domače pokrajine. 1. natis. Ljubljana, Mladinska knjiga, 1989, 110 str. (Soavtorji: Andrej Černe, Božidar Kert, Marijan M. Klemenčič, Franc Lovrenčak, Mirko Pak)

Geografija. Domača pokrajina. Delovni zvezek za geografsko proučevanje domače pokrajine. 1. natis. Ljubljana, Mladinska knjiga, 1989, 111 str. (Srednje usmerjeno izobraževanje) (Soavtorji: Slavko Brinovec, Andrej Černe, Božidar Kert, Marijan M. Klemenčič, Franc Lovrenčak, Mirko Pak)

Obča geografija za 1. letnik srednjih šol. 1. izd. Ljubljana, DZS, 1995, 265 str. (Soavtorji: Marijan M. Klemenčič, Franc Lovrenčak, Marjan Luževič, Mirko Pak, Jurij Senegačnik, Aleksander Jakoš)

2. izd., 1996.

3. izd., 1997.

4. izd., 1998.

5. izd., 1999. 
6. izd., 2000.

7. izd., 2001.

Obča geografija za 1. letnik srednjih šol. Delovni zvezek. 1. izd. Ljubljana, DZS, 1996, 77 str. (Soavtorji: Borut Drobnjak, Marijan M. Klemenčič, Franc Lovrenčak, Marjan Luževič, Mirko Pak, Jurij Senegačnik)

2. izd., 1997.

3. izd., 1998.

4. izd., 1999.

5. izd., 2000.

6. izd., 2001.

7. izd., 2002.

8. izd., 2003.

Obča geografija. Slikovno gradivo iz učbenikov Obča geografija in geografija za srednje šole. CD-ROM za učitelje. Ljubljana, DZS, 2000. (Soavtorji: Franc Lovrenčak, Ana Vovk Korže, Borut Drobnjak, Mirko Pak, Marjan Luževič, Marijan M. Klemenčič)

Geografija za srednje šole. Za programe, ki imajo za predmet geografija namenjenih do 140 ur. 1. izd. Ljubljana: DZS, 1997, 285 str. (Soavtorji: Franc Lovrenčak, Jurij Senegačnik, Borut Drobnjak, Mirko Pak, Marjan Luževič, Marijan M. Klemenčič)

1. izd., 2. natis, 2000.

1. izd., 3. natis, 2001.

1. izd., 4. natis, 2002.

1. izd., 5. natis, 2003.

1. izd., 6. natis, 2004.

Geografija. 1. izd. Ljubljana, DZS, 1999, 131 str. (Družboslovje) (Soavtorji: Igor Lipovšek, Mirko Pak, Marjan Luževič, Marijan M. Klemenčič)

1. izd., 2. natis, 2000.

1. izd., 3. natis, 2004.

1. izd., 4. natis, 2007.

1. izd., 5. natis, 2009.

1. izd., 6. natis, 2010.

1. izd., 7. natis, 2011.

Geografija. Delovni zvezek. 1. izd. Ljubljana, DZS, 1999, 79 str. (Družboslovje) (Soavtorji: Igor Lipovšek, Mirko Pak, Marjan Luževič, Marijan M. Klemenčič)

1. izd., 2. natis, 2000.

Geografija. Priročnik za učitelje. 1. izd. Ljubljana, DZS, 2001, 176 str. (Družboslovje) (Soavtorji: Igor Lipovšek, Mirko Pak, Marjan Luževič, Franci Novak, Senja Požar Podlesnik)

\section{Učni načrti, predmetni izpitni katalogi}

Geografija 1998. Ljubljana, Državni izpitni center, 1996, 38 str. (Predmetni izpitni katalog za maturo) (Soavtorji: Slavko Brinovec, Karmen Cunder, Alenka Dragoš, Mária Gaál, Rozika Klasinc, Karmen Kolenc Kolnik, Franc Lovrenčak, Jurij Senegačnik) 
Geografija 1999. Ljubljana, Državni izpitni center, 1997, 38 str. (Predmetni izpitni katalog za maturo) (Soavtorji: Slavko Brinovec, Karmen Cunder, Alenka Dragoš, Mária Gaál, Rozika Klasinc, Karmen Kolenc Kolnik, Franc Lovrenčak, Jurij Senegačnik, Franco de Simone)

Geografija 2003. Ljubljana, Državni izpitni center, 2001. 41 str. (Predmetni izpitni katalog za maturo) (Soavtorji: Slavko Brinovec, Karmen Cunder, Alenka Dragoš, Mária Gaál, Rozika Klasinc, Karmen Kolenc Kolnik, Franc Lovrenčak)

Učni načrt za geografijo. 1. natis. Ljubljana, Zavod Republike Slovenije za šolstvo, 1996. 25 str. (Soavtorji: Karmen Cunder, Nevenka Cigler, Vera Bevc Malajner, Branka Gabrenja-Müller, Jurij Senegačnik)

Osnutek učnega načrta in kataloga znanj za geografijo v programih, kjer je 210 ur geografije. Ljubljana, Zavod Republike Slovenije za šolstvo, 1997, 64 str. (Soavtorji: Karmen Cunder, Andrej Černe, Neva Osterman, Marta Otič, Jurij Senegačnik, Vera Bevc)

Učni načrt. Osnutek. Osnovna šola. Zemljepis. Ljubljana, Zavod Republike Slovenije za šolstvo, 1997. 70 str. (Soavtorji: Vera Bevc, Andrej Černe, Karmen Cunder, Jurij Senegačnik, Marta Otič, Neva Osterman)

Predlog učnega načrta v ekonomski gimnaziji. Geografija. Ljubljana, Nacionalni kurikularni svet, Predmetna kurikularna komisija za geografijo, 1998, 62 str. (Soavtorji: Andrej Černe, Karmen Cunder, Jurij Senegačnik, Marta Otič, Neva Osterman)

Predlog učnega načrta v klasični gimnaziji. Geografija. Ljubljana, Nacionalni kurikularni svet, Predmetna kurikularna komisija za geografijo, 1998, 62 str. (Soavtorji: Andrej Černe, Karmen Cunder, Jurij Senegačnik, Marta Otič, Neva Osterman)

Predlog učnega načrta v splošni gimnaziji. Geografija. Ljubljana, Nacionalni kurikularni svet, Predmetna kurikularna komisija za geografijo, 1998, 68 str. (Soavtorji: Andrej Černe, Karmen Cunder, Jurij Senegačnik, Marta Otič, Neva Osterman)

Predlog učnega načrta v strokovnih gimnazijah. Geografija. Ljubljana, Nacionalni kurikularni svet, Predmetna kurikularna komisija za geografijo, 1998, 17 str. (Soavtorji: Andrej Černe, Karmen Cunder, Jurij Senegačnik, Marta Otič, Neva Osterman)

Predlog učnega načrta za geografijo v programih, kjer je predmetu namenjenih 210 ur. V dvojezičnih šolah. Ljubljana, Nacionalni kurikularni svet, Predmetna kurikularna komisija za geografijo, 1998, 65 str. (Soavtorji: Andrej Černe, Karmen Cunder, Jurij Senegačnik, Marta Otič, Neva Osterman)

Predlog učnega načrta za geografijo v programih, kjer je predmetu namenjenih 210 ur. V šolah z italijanskim učnim jezikom. Ljubljana, Nacionalni kurikularni svet, Predmetna kurikularna komisija za geografijo, 1998, 66 str. (Soavtorji: Andrej Černe, Karmen Cunder, Jurij Senegačnik, Marta Otič, Neva Osterman)

Učni načrt. Predlog. Geografija za 9-letno osnovno šolo. Ljubljana, Nacionalni kurikularni svet, Predmetna kurikularna komisija za geografijo, 1998. 72 str. (Soavtorji: Andrej Černe, Karmen Cunder, Jurij Senegačnik, Marta Otič, Neva Osterman)

Posodobitev sedaj veljavnega učnega načrta za zemljepis. Priloga k sedaj veljavnemu učnemu načrtu. Ljubljana, 1999. 61 str. (Soavtorji: Vera Bevc, Andrej Černe, Karmen Cunder, Jurij Senegačnik, Marta Otič, Neva Osterman) 
Učni načrt. Osnovna šola z italijanskim učnim načrtom. Geografija. Ljubljana, Državni izpitni center, 1999. 79 str.

Učni načrt. Izbirni predmet, program osnovnošolskega izobraževanja. Geografija. Življenje človeka na Zemlji, raziskovanje domačega kraja in varstvo njegovega okolja. 1. natis. Ljubljana, Ministrstvo za šolstvo, znanost in šport, Zavod RS za šolstvo, 2001. 14 str. (Soavtorji: Vera Bevc, Andrej Černe, Karmen Cunder, Jurij Senegačnik, Marta Otič, Neva Osterman)

Ponatis, 2002

2. natis, 2004

Učni načrt. Program osnovnošolskega izobraževanja. Geografija. 1. natis. Ljubljana, Ministrstvo za šolstvo, znanost in šport, Zavod RS za šolstvo, 2001. 66 str. (Soavtorji: Vera Bevc Malajner, Karmen Cunder, Andrej Černe, Marta Otič, Neva Osterman, Jurij Senegačnik)

Ponatis, 2002

2. natis, 2003

\section{Raziskave, elaborati, študije}

Ilovice in opekarništvo v Ribniški dolini. Ljubljana, RSS, 1961. 54 str. (Soavtor)

Geološke, geomorfološke in hidrogeološke raziskave Kaninskega pogorja. Ljubljana, Geološki zavod, 1976. 2 zv. (Nosilec)

Gospodarsko geografski elementi in procesi socialistične preobrazbe pokrajine na območju komun Škofja Loka in Celje. Ljubljana, Inštitut za geografijo Univerze v Ljubljani, 1966, 369 str. (Soavtor)

Bohinj, Ribčev laz, Stara Fužina. Detajlni načrt. Bled, Zavod za urbanizem; Pariz, OTAM, 1972. 63 str. (Projekt Gornji Jadran) (Soavtor)

Določitev optimalne metode prenosa podatkov in optimalne gostote osnovne mreže reliefa Slovenije za digitalno uporabo. Ljubljana, RSS, 1972, 96 str. (Soavtor)

IV. jugoslovanska alpinistična himalajska odprava, Makalu 1972. Prispevek h glacialni geomorfologiji doline Baruna v Khumbakarna Himalu - Vzhodni Nepal. Ljubljana, Planinska zveza Slovenije, 1974. 92 str.

Regionalna geografska raziskava Zgornjega Posočja. Ljubljana, Inštitut za geografijo Univerze v Ljubljani, 1976, 251 str. (Soavtor)

Pokrajinska struktura in problematika severozahodnega Alpskega sveta Slovenije. Zaključno poročilo o rezultatih znanstveno-raziskovalnega dela na področju temeljnega raziskovanja. Ljubljana, Filozofska fakulteta, 1997, 66 str. (Nosilec)

Evalvacija kurikularne prenove geografije s posebnim poudarkom na standardih znanja ter načrtovanju in izvajanju vzgojno-izobraževalnega dela. Ljubljana, Znanstveni inštitut Filozofske fakultete, 2002, 59 str. (Nosilec)

Mednarodna naravoslovno zgodovinska učna pot 'Od bronaste dobe do bovških rudarjev, Bovec-Predel-Rabelj’. Gradivo za vodnik in za obvestila. Bovec, Občina Bovec, 2002. 68 str. (Nosilec) 


\section{Povzetki prispevkov na konferencah}

Kvantitativna tehnika v sodobni geografiji. V: Povzetki referatov v sekcijah. Vodnik po poti ekskurzij. Ljubljana, Geografsko društvo Slovenije, 1969, str. 17-18.

The high mountainous karst of Julian Alps in the system of the alpine karsts. V: Abstracts of papers. Budapest, 1971, str. 89.

Geographical consequences of a peripheral and border location. The case of the Upper Soča Valley in the Slovenian Alps. V: Conference abstracts. Prague, 1994, str. 86.

On morphogenesis of the superimposed valley of Soča River (Isonzo), Western Julian Alps. V: Fourth International conference on geomorphology, Bologna (Italia), 28. VIII-3. IX 1997. Abstracts. Torino, Comitato glaciologico Italiano, 1997, str. 237. (Geografia fisica e dinamica quaternaria. Supplemento, 1, III)

Strokovni in osebnostni razvoj učiteljev geografije v vseh življenjskih obdobjih. V: 12 . Ilešičevi dnevi, 27. do 29. september 2001, Filozofska fakulteta, Ljubljana. Ljubljana, Univerza v Ljubljani, Filozofska fakulteta, Oddelek za geografijo, 2001, str. 1.

Šolska geografija kot aplikacija stroke. V: Prospects of applied geography = Geografija in njene aplikativne možnosti. Znanstveno in strokovno posvetovanje. Program, povzetki. Ljubljana, Filozofska fakulteta, Oddelek za geografijo, 2002, str. 56.

Gorski svet Slovenije, problematika geomorfološkega raziskovanja. V: Vodnik po programu, ekskurzijah, predavanjih in povzetkih posterjev. Ljubljana, Geomorfološko društvo Slovenije, 2005, str. 25-26.

$\mathrm{K}$ pojmom skladna in neskladna pobočja in zvezah z geološko strukturo Slovenije. Problem interpretacije in terminologije. V: Vodnik po programu, ekskurzijah, predavanjih in povzetkih posterjev. Ljubljana, Geomorfološko društvo Slovenije, 2005, str. 35-36.

Vloga fizične geografije (geomorfologije) v poljudnih razlagah in promociji reliefa kot pokrajinske sestavine, na primeru TNP-ja. V: Fizična in okoljska geografija v teoriji in praksi. Znanstveni posvet in okrogla miza, 19. september 2007, Bohinj, Hotel Zlatorog. V počastitev osemdesetletnice rednega profesorja dr. Darka Radinje. Ljubljana, Filozofska fakulteta, Oddelek za geografijo, 2007, str. 19.

\section{Sestavki v enciklopedijah in leksikonih}

Enciklopedija Jugoslavije. 2. izd. Zagreb, Jugoslavenski leksikografski zavod Miroslav Krleža.

Knj. 6 (1990): Kanin.

Enciklopedija Slovenije. Ljubljana, Mladinska knjiga, 1987-2002.

Knj. 1 (1987): Boka. Bovec (Soavtor). Bovško. (Soavtor)

Knj. 3 (1989): Habe France. Habič Peter.

Knj. 4 (1990): Kanin.

Knj. 5 (1991): Koritnica. Kranjec Silvo. (Soavtor)

Knj. 6 (1992): Ledenik. Lovrenčak Franc.

Knj. 8 (1994): Planina France. 
Knj. 9 (1995): Podor. Posočje (Soavtor). Predel. (Soavtor)

Knj. 10 (1996): Rabelj (Soavtor). Rabeljska dolina (Soavtor)

Knj. 13 (1999): Šolska geografija. Terasa. Tolmin (Soavtor). Tolminsko (Soavtor).

Trenta (Soavtor). Triglav (Soavtor). Triglavska jezera. Triglavsko brezno.

Knj. 14 (2000): Vintgar. Visokogorski kras. Vogel. Vršič. Vršaj.

Geografski terminološki slovar. Ljubljana, Založba ZRC, ZRC SAZU, 2005. 451 str.

(Soavtor)

\section{Uvodniki}

K Ilešičevim dnevom 1991 in novi publikaciji. Geografija v šoli 1 (1991), str. 5-6.

Urednikova beseda. Geografija v šoli 2 (1992), str. 5.

Nagovor ob 7. Ilešičevih dnevih. Geografija v šoli 3 (1993), str. 6-8.

Urednikova beseda. Geografija v šoli 3 (1993), str. 5.

Raziskovanje slovenskega alpskega sveta. V: Geografska problematika slovenskega alpskega sveta in slovenskih mest. Ljubljana, Oddelek za geografijo Filozofske fakultete, 1995, str. 6-7. (Dela, 11)

70 let izhajanja Geografskega vestnika. Geografski vestnik 70 (1998), str. 7-8.

Alpe - naš skupni strokovni interes. V: Sonaravni razvoj v slovenskih Alpah in sosedstvu.

Ljubljana, Oddelek za geografijo Filozofske fakultete, 1999, str. 7-9. (Dela, 13)

Soškim razgovorom na pot. V: Soški razgovori I. Zbornik za domoznanstvo Zgodovinske sekcije KD Golobar, 2002, str. 13-18.

Moji spomini na Kamniško Bistrico - knjigi Tomaža Kočarja na pot. V: Kamniška Bistrica, Bistriški gozd. Ljubljana, samozal., 2003, str. 5-6.

Uvod, namen in izhodišča. V: Slovenska šolska geografija s pogledom v prihodnost. Ljubljana, DZS, 2005, str. 6-12.

Predgovor. V: Blaž Kocen. Življenje in delo. Šentjur, Občina Šentjur, 2007, str. 4-6.

O simpoziju in prireditvah v spomin Blaža Kocena in zborniku na pot. V: Blaž Kocen, 1821-1871. Življenje in delo očeta Kocenovih atlasov. Ljubljana, Slovenska matica, 2009, str. 7-9.

Uvodnik k tematski številki Geografije v šoli o vulkanizmu. Geografija v šoli 20 (2011), št. 1 , str. 4-10.

\section{Recenzije}

Speläologisches Fachwörterbuch. (Fachwörterbuch der Karst- und Höhlenkunde). Akten des Dritten Internationalen Kongresses für Speläologie Wien - Obertraun Salzburg 1961. Band C. Wien 1965, 109 strani. Geografski vestnik 38 (1966), str. 158-159.

Ivan Gams, Some morphological characteristics of the Dinaric Karst. The Geographical Journal, Vol. 135, part 4, December 1969. London, str. 563-572. Dva kartograma. Geografski vestnik 42 (1970), str. 137-138. 
Problems of the Karst Denudation. Edited by Otakar Štelcl. Československá akademie věd - Geograficky ústav, Brno. Studia geographica 5. Supplement for the 5th International Speleological Congress, Stuttgart 1969. Brno 1969. 166 strani. Geografski vestnik 42 (1970), str. 138-142.

Acta carsologica V. Inštitut za raziskovanje krasa Slovenske akademije znanosti in umetnosti. Uredil Srečko Brodar ob sodelovanju Valterja Bohinca in Romana Savnika, Ljubljana 1970. Geografski vestnik 43 (1971), str. 170-172.

Gavrilović Dušan, Srpska kraška terminologija. Kraška terminologija jugoslovenskih naroda, knjiga II. Savez geografskih društava Jugoslavije. Beograd 1974, 73 strani. Geografski vestnik 46 (1974), str. 152-153.

Karst Geomorphology (uredila M. M. Sweeting). Benchmark Papers in Geology, 59, Stroudsburg, Pennsylvania, Hutchinson Ross Publishing Company, 1981, str. 427. Geografski vestnik 55 (1983), str. 122-123.

Stephen Trudgill, Limestone Geomorphology. Geomorphology texts 8. Uredil K. M. Clayton. Longman, London in New York. 196 strani. 1985. Geografski vestnik 58 (1986), str. 128-129.

Bognar Andrija: Geomorfologija Baranje, znanstvena monografija. Savez geografskih društava Hrvatske, Posebna izdanja, svezak 7. Zagreb 1990, str. 312. Geografski vestnik 63 (1991), str. 136-138.

Fenomen krš, Srečko Božičević, izdala Školska knjiga, Zagreb 1992. Proteus 55 (1992/1993), št. 3, str. 118.

Nov učni pripomoček. Slovenija na videu. Šolski razgledi 45 (14. feb.1994), št. 3, str. 15.

Didaktična revija Praxis Geographie. Geografija v šoli 5 (1996), št. 1, str. 38-39.

Nov učbenik za Občo geografijo in poskus didaktične analize. Geografija v šoli 5 (1996), št. 1, str. 28-31.

Kras v Sloveniji v prostoru in času. Knjiga akademika prof. dr. Ivana Gamsa. Kras 2005, št. 72, str. 46-47.

Slovenska šolska geografija s pogledom v prihodnost - priročnik za učitelje geografije. Geografija v šoli 14 (2005), št. 1, str. 59-63.

Dolina Triglavskih jezer - geomorfološki pogled. Bojan Erhartič: Geomorfološka dediščina v Dolini Triglavskih jezer. Ljubljana, Založba ZRC SAZU, 2012. 187 str. Planinski vestnik 113 (2013), št. 3, str. 66.

\section{Intervjuji}

Novi in poznani obrazi na Oddelku za geografijo. Geomix 8 (dec. 2001), št. 1, str. 6-7. (Soavtorji: Vanja Šendlinger, Simon Kušar, Katja Vintar Mally, Monika Benkovič Krašovec)

Počasi lahko začno tudi paradižniki leteti po zraku, češ, ja kaj si pa ti dovolil. Prosvetna zbornica 2001, št. 1, str. 5-7.

Prof. dr. Jurij Kunaver, o metodi izobraževalne ekskurzije in o razsežnostih prostora. Andragoška spoznanja 13 (2007), št. 1, str. 90-95. 
Naravna okna v naših gorah. Pogovor s prof. dr. Jurijem Kunaverjem. Planinski vestnik 108 (2008), št. 4, str. 7-10.

Prof. dr. Jurij Kunaver. Intervju v oddaji Podobe znanja, Radio Slovenija, Tretji program ARS, 12. jul. 2013.

\section{Biografski zapisi}

Profesorju Dušanu Komparetu v slovo. Geografski vestnik 54 (1982), str. 139-140.

Ob odkritju spominske plošče prof. dr. Antonu Meliku. Geografski vestnik 55 (1983), str. 19-23.

Častnemu članu Geografskega društva Slovenije profesorju dr. Valterju Bohincu v slovo. Geografski obzornik 31 (1984), št. 1, str. 72-74.

V spomin Valterja Bohinca. Proteus 47 (1984/1985), št. 3, str. 113.

Nepozabnemu učitelju profesorju Ilešiču v slovo. Geografski obzornik 32 (1985), št. 1 , str. 3-5.

Petinosemdeset let dr. Romana Savnika. Geografski vestnik 59 (1987), str. 189-191.

Dr. Milan Šifrer - šestdesetletnik. Geografski vestnik 60 (1988), str. 179-181.

Dr. Primož Krivic, 27. 3. 1950-26. 2. 1990. Naše jame 32 (1990), str. 118-120.

Jubilej profesorice Mare Radinjeve. Geografski obzornik 37 (1990), št. 2, str. 55-56.

(Soavtor: Milan Natek)

France Planina - devetdesetletnik. Delo 33 (1. okt. 1991), št. 230, str. 7.

Profesor France Planina - devetdesetletnik. Geografski vestnik 63 (1991), str. 171-172.

Profesor Hinko Uršič - osemdesetletnik. Geografski vestnik 63 (1991), str. 172-174.

Spominski zapis ob smrti profesorja Franceta Planine. Geografski vestnik 64 (1992), str. 256-259.

Ivanu Gamsu ob 70 letnici. Geografski vestnik 65 (1993), str. 5-8.

In memoriam Marjorie M. Sweeting (1920-1994). Acta carsologica 24 (1995), str. 587-589.

Marjorie M. Sweeting (1920-1994). Geografski vestnik 67 (1995), str. 201-203.

Didaktični opus profesorja Svetozarja Ilešiča in njegov pomen za razvoj slovenske šolske geografije. Geografija v šoli 5 (1996), št. 2, str. 10-14.

Dr. Metod Vojvoda - šestdesetletnik. Geografski vestnik 69 (1997), str. 231-234.

Ob stoletnici rojstva dr. Valterja Bohinca. Naše jame 40 (1998), str. 170-172.

Petru Habiču v slovo. Naše jame 40 (1998), str. 186-189.

France Habe (1909-1999). Naše jame 41 (1999), str. 149-151.

Ob grobu dr. Franceta Habeta, Postojna, pokopališče, 14. 10. 1999. Geografski vestnik 71 (1999), str. 184-186.

Profesor Svetozar Ilešič kot pedagog, Ljubljana, Zemljepisni muzej Slovenije, 4. 2. 1999. Geografski vestnik 71 (1999), str. 175-176.

France Planina, pisec geografskih del, kartograf in učitelj geografije. V: Bibliografija profesorja Franceta Planine, 1901-1992. Škofja Loka, Knjižnica Ivana Tavčarja, 2001, str. 28-34. (Bibliografije pomembnih osebnosti s Škofjeloškega) 
Življenje in delo akademika Ivana Gamsa $=$ The life and work of academicean Ivan Gams. V: Bibliografija akademika Ivana Gamsa = Bibliography of academician Ivan Gams. Ljubljana, Slovenska akademija znanosti in umetnosti, 2005. (Bibliografije akademikov, 1) URL: http://www.sazu.si/files/file-12.pdf (Citirano 24. 9. 2013)

In memory of Marian Pulina (1936-2005). Acta carsologica 35 (2006), št. 1, str. 163-165. Slavko Brinovec - sedemdesetletnik, Kranj, 25. 4. 2006. Geografski vestnik 78 (2006), št. 1, str. 112-115.

V spomin Marianu Pulini (1936-2005), Katowice, Poljska, 22. 10. 2005. Geografski vestnik 78 (2006), št. 2, str. 134-137.

Profesor Svetozar Ilešič - ob stoti obletnici rojstva. Geografija v šoli 16 (2007), št. 3, str. 57-59.

Janez Jesenko - pomemben geograf in mislec druge polovice 19. stoletja. Glasnik Slovenske matice 32 (2008), str. 167-181. (Soavtorji: Rožle Bratec Mrvar, Drago Kladnik, Renato Vidrih)

Geološki park Karnijske Alpe. V spomin na profesorja geologije Stanka Buserja. Geografski obzornik 56 (2009), št. 1/2, str. 32-37.

Prof. dr. Hartwig Haubrich, dobitnik najvišjega priznanja Mednarodne geografske unije. Geografija v šoli 18 (2009), št. 1, str. 78-81.

Začetnik naše znanstvene in šolske geografije. Slovenska matica o Janezu Jesenku (1838-1908). Delo 51 (8. jan. 2009), št. 5, str. 17.

Dr. Anton Melik, največji slovenski geograf (1. 1. 1890-8. 6. 1966). Ob stodvajsetletnici njegovega rojstva. Geomix 16 (maj 2010), št. 2, str. 21-23.

Akad. Ivan Gams, 90-letnik. Delo 55 (19. sep. 2013), št. 217, str. 14.

\section{Poročila}

Mednarodna speleološka konferenca v Brnu od 29. junija do 4. julija 1964. Geografski vestnik 36 (1964), str. 108-110.

Pred četrtim mednarodnim speleološkim kongresom v Jugoslaviji v letu 1965. Geografski vestnik 36 (1964), str. 128-129.

25. mednarodni geografski kongres v Parizu 1984. Geografski vestnik 57 (1985), str. 111-120. (Soavtorji: Borut Belec, Ivan Gams, Matjaž Jeršič, Franc Lovrenčak, Mirko Pak)

Častitljiv jubilej slovenskih geografov. Dolenjski list 36 (24. jan. 1985), št. 4, str. 20.

12. kongres geografov Jugoslavije Novi Sad 29. 9.-6. 10. 1985. Geografski vestnik 58 (1986), str. 151-152.

1. znanstveno srečanje geomorfologov Jugoslavije, Bovec, 12.-17. 9. 1986. Geografski vestnik 59 (1987), str. 198-201.

Ekskurzija Ljubljanskega geografskega društva na Dunaj, 28. do 30. junija 1986. Geografski vestnik 59 (1987), str. 210-212.

Ilešičevi dnevi 1988. Geografski obzornik 35 (1988), št. 1, str. 82-85.

Geografija in aktualna vprašanja prostorskega razvoja. Geografski vestnik 62 (1990), str. $183-184$. 
Okrogla miza Optimizacija in vertikalna strukturiranost pouka geografije. Geografski vestnik 62 (1990), str. 184-185.

Ilešičevi dnevi 1991. Geografski obzornik 38 (1991), št. 1, str. 43.

Poročilo o 6. zasedanju stalne evropske konference združenj učiteljev geografije. Geografski obzornik 38 (1991), št. 1, str. 38-40.

27. mednarodni geografski kongres v Washingtonu. Geografski vestnik 64 (1992), str. 266-269.

Slovenija je postala član Mednarodne geografske unije. (Poročilo o 18. generalni skupščini Mednarodne geografske unije, 10.-12. avgust 1992, Washington). Geografski vestnik 64 (1992), str. 269-272.

Mednarodni didaktični simpozij Evropska dimenzija pouka geografije. Slovenija in sosedstvo. Šolski razgledi 44 (22. feb. 1993), št. 4, str. 12.

Sedmi Ilešičevi dnevi. Permanentno izobraževanje geografov. Šolski razgledi 44 (22. feb. 1993), št. 4, str. 12.

17. zborovanje slovenskih geografov na Ptuju. Geografski obzornik 42 (1995), št. 4, str. 3. (Soavtorji: Mirko Pak, Bibijana Mihevc, Marjeta Vidmar)

O pomembnejših mednarodnih srečanjih o šolski geografiji v letu 1994 in delovanju Komisije za geografsko vzgojo IGU. Geografija v šoli 4 (1995), št. 1, str. 163-165.

4. mednarodni geomorfološki kongres v Bologni, 28. 8.-3. 9. 1997. Geografski vestnik 69 (1997), str. 259-261.

Dekani se spominjajo. Dr. Jurij Kunaver, redni profesor, dekan od 1977/78 do 1978/79. V: Zbornik ob 50-letnici Višje pedagoške šole, Pedagoške akademije, Pedagoške fakultete. Ljubljana, Modrijan, 1997, str. 81-83.

Poročilo o 10. Ilešičevih dnevih, 6.-8. november 1997. Novice / Oddelek za geografijo 1997, št. 3, str. 7-8.

Priznanja Zveze geografskih društev Slovenije. Geografski obzornik 46 (1999), št. 4, str. 24-27. (Soavtorja: Milan Natek, Milan Orožen Adamič)

Prizadevanja za kakovostno izobraževanje bodočih učiteljev geografije. Ob okrogli mizi na 11. Ilešičevih dnevih in obisku na Pedagoški fakulteti v Mariboru. Geografski obzornik 47 (2000), št. 1, str. 22-26. (Soavtorica: Karmen Kolenc Kolnik)

Evropska dimenzija pouka geografije v luči mednarodnega simpozija tranzicijskih držav. Maribor, 29.-31. marec 2001. Geografija v šoli 10 (2001), št. 2, str. 31-37.

Priznanja Društva učiteljev geografije Slovenije za leto 2001, Ljubljana, 27. 9. 2001. Geografski vestnik 73 (2001), št. 2, str. 75-77.

Prva podelitev priznanj Društva učiteljev geografije Slovenije. Geografija v šoli 11 (2002), št. 1, str. 88-90.

Druga podelitev priznanj Društva učiteljev geografije Slovenije. Geografija v šoli 12 (2003), št. 3, str. 68-70.

Priznanja Društva učiteljev geografije Slovenije. Geografija v šoli 14 (2005), št. 2, str. $58-59$.

Blasius Kozenn - Vater der Schulatlanten. Die Feier im April 2009 in Hotunje (Slowenien). Mitteilungen der Österreichischen Geographischen Gesellschaft 151 (2009), str. 311-314. 


\section{Uredniško delo}

Slovenska kraška terminologija. Ljubljana, Katedra za fizično geografijo Oddelka za geografijo FF, 1973, 76 str. (Kraška terminologija jugoslovanskih narodov, 1)

Vodnik ekskurzij po Zgornjem Posočju. Ljubljana, Geografsko društvo Slovenije, 1975, 39 str.

Zgornje Posočje. Zbornik 10. zborovanja slovenskih geografov, Tolmin - Bovec, 26.28. 9. 1975. Ljubljana, Geografsko društvo Slovenije, 1978, 394 str.

Karst and man. Proceedings of the International symposium on human influence in karst, 11-14th September 1987, Postojna, Yugoslavia. Ljubljana, Department of Geography, Philosophical Faculty, 1987, 265 str.

Pokrajina in ljudje na Bovškem. Ljubljana, Republiški koordinacijski odbor Gibanja Znanost mladini pri Zvezi organizacij za tehnično kulturo Slovenije, 1988, 174 str.

Zbornik referatov seminarja permanentnega izobraževanja. 5. Ilešičevi dnevi, Ljubljana, 22.-23. 2. 1991. Ljubljana, Filozofska fakulteta, Oddelek za geografijo; Zveza geografskih društev Slovenije, 1991, 101 str. (Geografija v šoli, 1)

Zbornik referatov seminarja permanentnega izobraževanja. 6. Ilešičevi dnevi, Ljubljana, 21.-22. 2. 1992. Ljubljana, Filozofska fakulteta, Oddelek za geografijo, 1992, 139 str. (Geografija v šoli, 2)

Zbornik referatov seminarja permanentnega izobraževanja. 7. Ilešičevi dnevi, Ljubljana, 26.-27. 2. 1993. Ljubljana, Filozofska fakulteta, Oddelek za geografijo, 1993, 164 str. (Geografija v šoli, 3)

Soški razgovori I. Zbornik za domoznanstvo Zgodovinske sekcije KD Golobar. Bovec, Zgodovinska sekcija Kulturnega društva Golobar, 2002, 298 str.

Blaž Kocen, 1821-1871. Življenje in delo očeta Kocenovih atlasov. Ljubljana, Slovenska matica, 2009, 130 str.

Kaninsko pogorje in učna pot na Prestreljeniških podih. Naravoslovni, zgodovinski in turistični vodnik. Bovec, Turistično društvo, 2011, 168 str.

Geografija v šoli. ISSN 1318-4717. Ljubljana, Zavod Republike Slovenije za šolstvo. (član uredniškega odbora od leta 1995)

Dela. ISSN 0354-0596. Ljubljana, Oddelek za geografijo Filozofske fakultete Univerze v Ljubljani. (odgovorni urednik 1992-1993, glavni urednik 1999, član uredniškega odbora 1991, 1999-2000, 2002)

\section{Mentor}

\section{Doktorske disertacije}

Kolenc Kolnik, Karmen. Mednarodno razumevanje in sodelovanje v luči geografske vzgoje in izobrazbe. Na primeru slovensko-italijanskega in slovensko-madžarskega obmejnega prostora. Celje, 1996. 
Bratun, Zvonimir. Geografski dejavniki državnovarnostnega sistema Republike Slovenije. Ljubljana, 1997.

Resnik Planinc, Tatjana. Zahtevnejše geografske učne vsebine kot izobraževalni problem. Ljubljana, 2001.

Umek, Maja. Kartografsko opismenjevanje osnovnošolcev v Sloveniji. Ljubljana, 2001.

Popit, Sabina. Vrednotenje dodiplomskega izobraževanja učiteljev geografije z vidika njene paradigmatične zgradbe. Ljubljana, 2002. (Somentor)

Kladnik, Drago. Tuja zemljepisna imena v slovenskem jeziku. Razvojni vidiki in problematika njihove rabe. Ljubljana, 2006.

Erhartič, Bojan. Naravovarstveno vrednotenje geomorfološke dediščine v Dolini Triglavskih jezer z metodo geomorfološkega kartiranja. Ljubljana, 2011.

\section{Magistrska dela}

Umek, Maja. Metodične smernice za geografski pouk v tretjem letniku usmerjenega izobraževanja: geografija domače pokrajine. Ljubljana, 1990.

Resnik Planinc, Tatjana. Evropska dimenzija pouka geografije v Sloveniji. Ljubljana, 1998.

Popit, Sabina. Učbenik kot pogoj učinkovitega pouka geografije. Ljubljana, 2000.

Konečnik Kotnik, Eva. Motiviranje učencev pri pouku geografije. Ljubljana, 2001. (Somentor)

Mrak, Irena. Sledovi pleistocenske morfogeneze v porečju Tržiške Bistrice. Tržič, 2003.

\section{Diplomska dela}

\section{Pedagoška akademija Univerze v Ljubljani}

Peterle, Verica. Novejša geografska preobrazba območja krajevnih skupnosti na Miljskih hribih s posebnim ozirom na mejno lego (krajevne skupnosti Ankaran, Hrvatini, Škofije, občina Koper). Ljubljana, 1986.

Gorenc, Jože. Geografija prebivalstva in naselij krajevne skupnosti Dolenjske Toplice s poudarkom na povojnem obdobju. Dolenjske Toplice, 1987. (Somentor)

Mestek, Andreja. Geografija krajevne skupnosti Cajnarje-Žilce. Dolenje Jezero, Cerknica, 1987.

\section{Filozofska fakulteta Univerze v Ljubljani}

Peperko, Dunja. Države vzhodnega Sredozemlja kot snov geografskega pouka v aktualni luči. Ljubljana, 1990.

Podboršek, Mateja. Geografija Vodiško-Skaručenske pokrajine. Primer lokalne geografije. Ljubljana, 1990. (Somentor)

Šifrar, Ana. Geografija krajevne skupnosti Gorenja vas. Ljubljana, 1990. (Somentor)

Blaževič, Metka. Polpuščavska in puščavska območja sveta kot snov geografskega pouka. Ljubljana, 1991.

Resnik, Tatjana. Dejavniki učinkovitosti pouka geografije v izbranih srednjih šolah. Ljubljana, 1991. 
Kuščer, Majda. Fizičnogeografske osnove pokrajinske strukture Dežele z didaktičnim vrednotenjem. Lesce, 1992.

Polšak, Anton. Novejša geografska preobrazba ožjega Kozjanskega in didaktično vrednotenje pokrajine. Planina, 1992.

Račič, Mateja. Težja učna snov pri pouku geografije na primeru matematične geografije. Ljubljana, 1992.

Štefanič, Nataša. Območje Loga v Trenti. Inventarizacija in valorizacija pokrajinskih danosti za potrebe Triglavskega narodnega parka. Ljubljana, 1992.

Kukec, Polonca. Računalnik kot inovacija pri pouku geografije. Stanje na izbranih šolah. Ljubljana, 1993.

Lavrač, Lydia. Domžalsko-moravški kras in njegova pokrajinska značilnost. Ljubljana, 1993.

Malej, Barbara. Planina Suha v Spodnjih Bohinjskih gorah. Geografija območja in planinskega gospodarjenja. Ljubljana, 1993.

Piciga, Jasmina. Projektno učno delo pri pouku zemljepisa. Ljubljana, 1993.

Bolta, Renata. Dolina Kamniške Bistrice kot območje geografskih šolskih ekskurzij Koželjeva učna pot. Radomlje, 1994.

Felicijan, Zdenka. Geomorfologija doline Motnišnice. Ljubljana, 1994.

Kalan, Urška. Video pri pouku geografije. Ljubljana, 1994.

Zgaga, Srečko. Geografska transformacija kulturne pokrajine v dolinah Koritnice, Kneže in sosedstva. Območje vasi Bača, Kal, Stržišče, Rut, Grant in Kneške Ravne. Ljubljana, 1994.

Jeraj, Mateja. Ekološko izobraževanje pri pouku geografije v osnovni in srednji šoli na primeru Šaleške doline. Ljubljana, 1995.

Kučiš, Natalija. Permanentno izobraževanje učiteljev geografije v Sloveniji. Ljubljana, 1995.

Račič, Jože. Motivacija pri pouku geografije v osnovni šoli v luči diferenciacije. Ljubljana, 1995.

Jarc, Nataša. Mesta kot snov v šolski geografiji na primeru Škofje Loke. Ljubljana, 1996.

Kramberger, Sabina. Izbrane fizičnogeografske vsebine v procesu izobraževanja v Sloveniji. Ljubljana, 1996.

Markovič, Katarina. Okoljske vsebine v srednješolskih programih geografije na primeru Ljubljane. Ljubljana, 1996.

Tonin, Tatjana. Projekti z vsebino varstva geografskega okolja pri pouku zemljepisa v osnovni šoli. Ljubljana, 1996.

Brenčič, Polona. Sosednje države Slovenije kot tema pri pouku geografije. Primer slovensko-hrvaškega sosedstva v Spodnjem Posavju. Ljubljana, 1997.

Brodnik, Urška. Rekreacijski pomen Triglavskega narodnega parka. Ljubljana, 1997.

Čož, Marjana. Geografske šolske ekskurzije in terensko delo na območju Zgornjega Posočja. Ljubljana, 1997.

Janša, Andreja. Poskusni priročnik za učitelje za pouk obče geografije. Fizičnogeografski del. Ljubljana, 1997. 
Majcen, Sonja. Geografija zahodnega dela Ljubljanskega barja in njegovo didaktično vrednotenje. Ljubljana, 1997.

Novak, Mojca. Stanje srednješolske geografije v Sloveniji v luči razvoja geografije v svetu. Primerjava z Zvezno republiko Nemčijo. Ljubljana, 1997.

Peršolja, Borut. Geografski problemi imenoslovja Kamniško-Savinjskih Alp. Ljubljana, 1997.

Polajžar, Stanislava. Študij primera pri pouku geografije. Teorija in praksa. Ljubljana, 1997.

Selič, Mija. Geomorfologija doline Triglavskih jezer s posebnim ozirom na ledeniško in kraško morfogenezo. Ljubljana, 1997.

Skerlovnik-Štrancar, Ana. Turistični podmladki kot interesna dejavnost v osnovni šoli in turistična geografija. Ljubljana, 1997.

Žgajnar, Mateja. Razvoj kraškega zemljišča in naselja Opatje selo. Ljubljana, 1997.

Bistrović, Tatjana. Ljubljana kot predmet geografskega pouka s poudarkom na terenskem delu. Ljubljana, 1998.

Eniko, Urška. Transformacija Bovškega v zadnjih dvesto letih. Historično-geografska analiza jožefinske vojaške karte in franciscejskega katastra. Ljubljana, 1998.

Grabljevec, Mojca. Geografija osrednjega dela Notranjskega Snežnika s poudarkom na naravoslovni učni poti. Ljubljana, 1998.

Jereb-Urh, Elizabeta. Blejski kot kot območje šolskih geografskih ekskurzij s posebnim ozirom na Blejski Vintgar. Radovljica, 1998.

Mandelj, Klavdija. Postojnska jama kot učna snov pri pouku geografije. Radovljica, 1998.

Prebilič, Vladimir. Geografska analiza območja Kočevske Reke za potrebe obrambe. Kočevje, 1998.

Rakovec, Aleksandra. Geografija Karavank od Stola do doline Mošenika s poudarkom na fizičnogeografskih potezah. Ljubljana, 1998.

Kljun, Lidija. Regionalna geografija Bloške planote in didaktična obravnava s pomočjo programa 'Power Point'. Ljubljana, 1999.

Makarovič, Marjana. Poskusni učbenik za učitelje pouka geografije v srednjih poklicnih šolah. Ljubljana, 1999.

Peric, Borut. Morfološke in metrične značilnosti udornic na območju Škocjanskega regijskega parka. Ljubljana, 1999.

Pesan, Irena. Poskusni priročnik za učitelje za pouk obče geografije. Družbenogeografski del. Celje, 1999.

Repe, Blaž. Poizkusni geografski atlas občine Grosuplje. Ljubljana, 1999.

Bratec-Mrvar, Rožle. Blaž Kocen (1821-71). Didaktik, kartograf in geograf. Ljubljana, 2000.

Fabjan, Vesna. Poskusni priročnik za učitelje geografije za organizacijo ekskurzije v Belo krajino. Črnomelj, 2000.

Komac, Blaž. Vodne razmere kraških izvirov na južnem podnožju Kaninskega pogorja. Bovec, 2000.

Koselj, Vesna. Poskusni priročnik za poučevanje krasa za učitelje osnovnih in srednjih šol. Ljubljana, 2000. 
Leskovic, Daniel. Geomorfološke značilnosti doline zgornje Krke in njen razvoj. Ljubljana, 2000.

Masterl, Saša. Grosupeljska pokrajina in njeno vrednotenje za potrebe šolske geografije. Ljubljana, 2000.

Povše, Urška. Geografski vplivi na kakovost vode v kraških izvirih na obrobju Trnovsko-Banjške planote. Ljubljana, 2000.

Jarh Milovanovič, Sebastjan. Poskus aplikacije sistemske teorije v geografiji krasa. Ljubljana, 2001.

Miklave Pintarič, Simona. Geografija gorstev na Zemlji. Didaktična problematika za potrebe planinskih krožkov in vzgoje gornikov. Ljubljana, 2001.

Rebec, Nataša. Poučevanje geografije v slovenskih šolah v Italiji v vlogi prekomejnega sodelovanja. Ljubljana, 2001.

Tomšič, Žarko. Razvoj in pomen tekmovanj iz znanja geografije. Ljubljana, 2001.

Mikec, Simona. Eksperiment kot učna metoda pri pouku geografije. Ljubljana, 2002.

Vrhovec, Jure. Speleogeneza jame Srnica in bližnjih jam na vznožju Kaninskega pogorja. Ljubljana, 2002.

\section{Fakulteta za družbene vede Univerze v Ljubljani}

Stopar, Tomaž. Obrambno vrednotenje geografskega prostora na območju Krške kotline z obrobjem. Ljubljana, 1996.

Zadek, Robert. Obrambno-geografska analiza povodja reke Drave med Dravogradom in Mariborom. Ljubljana, 1996.

Škarabot, Robertino. Demografski dejavnik v obrambnem sistemu Slovenije. Ljubljana, 1997.

Napotnik, Drago. Obrambno-geografska analiza energetske odvisnosti Slovenije. Ljubljana, 1998.

Kravanja, Cveto. Obrambno vrednotenje geografskega prostora Pivškega podolja in Vremščice. Ljubljana, 1999.

Pižorn, Emiljan. Obrambnogeografsko vrednotenje Srednjega Posotelja. Ljubljana, 1999.

Sitar, Gregor. Obrambno geografsko vrednotenje Velenjske kotline. Ljubljana, 2001.

Vogrin, Sergej. Obrambno geografsko vrednotenje Haloz. Ljubljana, 2001.

Koren, Mojca. Obveščevalna priprava bojišča v poveljstvih Slovenske vojske. Ljubljana, 2002.

Stergar, Gorazd. Prehodnost med Ljubljansko in Celjsko kotlino. Ljubljana, 2002.

Berčič, Katja. Obrambnogeografsko vrednotenje spodnjega dela Ljubljanske kotline. Ljubljana, 2003.

Štrancar, Monika. Vipavska dolina - obrambnogeografska analiza območja. Ljubljana, 2003.

Jenko, Blaž. Obrambnogeografsko vrednotenje Notranjskega podolja. Ljubljana, 2004.

Mulec, Suzana. Vreme - obrambnogeografski dejavnik. Ljubljana, 2004.

Praprotnik, Martina. Obrambnogeografska analiza območja Zgornjesavske doline. Ljubljana, 2004. 
Grozde, Jože. Geografski prostor kot osnova za bojne simulacije na primeru Trebanjske kotline. Ljubljana, 2005.

Klemen, Živa. Obrambnogeografsko vrednotenje Zasavja. Ljubljana, 2006.

\section{Pedagoška fakulteta Univerze v Mariboru}

Krnjič, Sandra. Učna motivacija kot eden od dejavnikov uspešnega učenja zemljepisa v osnovni šoli. Kidričevo, 1994.

\section{Zaključne naloge}

\section{Center vojaških šol Ministrstva za obrambo}

Cerkovnik, Janez. Vojaško geografska ocena smeri Starod-Kozina. Osnova za razmestitev obrambnih sil. Poljče, 1998. (Somentor)

Todorovski, Stojan. Vojaško geografske značilnosti Bele krajine. Ljubljana, 1998. (Somentor) 